Koch, Andrew M. and Rick Elmore. "Simulation and Symbolic Exchange: Jean Baudrillard's Augmentation of Marx's Theory of Value" Politics and Policy 34 (3) 556575. September, 2006. Wiley Blackwell (ISSN: 1555-5623) DOI: 10.1111/j.17471346.2006.00028.x Version of record at: http://0-www3.interscience.wiley.com

\title{
Simulation and Symbolic Exchange: Jean Baudrillard's Augmentation of Marx's Theory of Value
}

\author{
Andrew M. Koch and Rick Elmore
}

\begin{abstract}
Jean Baudrillard's concept of "symbolic exchange" represents an important concept in understanding why Marx's prediction regarding the collapse of capitalism has not been realized. Baudrillard adds to the Marxian concepts of use value and exchange value, suggesting that, in today's consumer-oriented society, commodities take on a symbolic value that constitutes their "status" and, therefore, power. In the Western industrial societies that are "networked" into information cultures, the generation of symbolic value results from a constantly changing symbolic environment in which new demands for access to symbolic status are generated. Baudrillard sees the United States as the farthest along on the path to a simulated environment of symbolic exchange. Manufacturing for symbolic exchange is directed toward the production of the fetish: an object that is positioned purely for its symbolic value. By directing production increasingly in the direction of the fetish, as an object to be used in symbolic exchange, capitalism is able to sustain itself even after the material needs of the population are satisfied.
\end{abstract}

\begin{abstract}
ARTICLE
Introduction

Questions surrounding production, distribution, and consumption have been central to discussions of politics since the time of Plato. These issues were given new relevance in the modern period by the analysis and critique of Karl Marx in his
\end{abstract}


discussion of the relationship between economic organizations and the distribution of power in society. However, despite Marx's prediction of capitalism's coming collapse, capitalism continues to expand, even into the twenty-first century. Marx's claims regarding capitalism's demise have not been manifest.

Critical political theory approaches theoretical discourse as an open rather than a closed process. Due to this approach, it can offer an explanation regarding the continued existence of the capitalist economic system that is both informed regarding the tenets of Marxist thought, and sympathetic to its aims, but which can also critique Marx's analysis and add to it conceptual base. Of particular interest in this regard is the work of the French social theorist, Jean Baudrillard. Along with Michel Foucault, Jacques Derrida, and others of the French movement known as postmodernism, Baudrillard is concerned with the intersections of power, social organization, and the material aspect of social life. However, the role played by Marxist thought in Baudrillard's writings has been an issue of debate among both his supporters and critics.

In the secondary literature on Baudrillard it is often argued that while Baudrillard was influenced by the work of Karl Marx in his early years, he made, with the publication of Mirror of Production, a conscious break with the Marxian project. As Dougles Kellner contends, with Mirror of Production "Baudrillard rejects Marxism entirely" (Kellner 1989, 39). The claim is that after his initial training in Marxist theory, Baudrillard became influenced by the writings of Nietzsche, Weber, and postmodernism. Mark Poster asserts a similar position (Poster, 1988). It is argued that these influences led Baudrillard away from his Marxist roots. Hence, as Paul Hegarty explains "Baudrillard's work has often been characterized as having a 'before and after', in terms of a break with Marxism" 
(Hagarty 2004, 13). Such a break would relegate the significance of production in Baudrillard's work to a secondary status.

However, in contrast to much of the secondary literature, this paper argues that Baudrillard never abandoned the central dynamic of the Marxian project. More specifically, Baudrillard remains interested in the way in which the conditions of production and consumption establish the context for the entire social order. Like Marx, Baudrillard sees production as undergoing developmental transformations. Both production and consumption alter the conditions in which the social and political institutions are formulated.

Baudrillard is interested in the question of how capitalism has continued to sustain itself amidst abundance. In order to explain this Baudrillard introduces the notion of "symbolic exchange" or "sign exchange." Sign exchange is a process in which goods are exchanged as commodities, but with the new element of symbolic value, or status, they provide the consumer. Symbolic value presents a new explanatory tool in the discussion of value and is designed to augment the explanatory power of use value and exchange value in a consumption oriented society (Baudrillard 1981, 123-29).

Such a claim allows Baudrillard to develop the idea of "fetishism" in the production process in a way that goes beyond the Marxian formulation. Marx introduces the idea of fetish value in the Economic and Philosophic Manuscripts of 1844. Over the last twenty years Baudrillard has built a conceptual framework for the understanding of fetishism within contemporary capitalism. This framework develops in the discussion of simulacrum and "simulation." Sign value emerges as the new key term for analyzing value in a consumer society, one in which the fetishism of commodities is complemented 
by a new fetishism attached only to the symbolic value of objects.

This work is divided into five sections. The first outlines Baudrillard's concept of simulation, which is essential to understanding the significance of symbolic and sign exchange in relation to Baudrillard's notion of the hyperreal. The second section discusses symbolic consumption as a manifestation of simulacrum and simulation proper. Section three draws on Baudrillard's discussion of America in order to examine the impact of later orders of simulacrum and fetishized production. Section four returns to Marx, examining the place of Baudrillard's orders of value in the context of Marxist theory. Section five deals with the significance of new kinds of fetishism for politics.

\section{Simulation: From Stucco to the Fetish}

Central to the understanding of Baudrillard's work is the concept of simulation. Baudrillard argues that our social reality is a construction, what he terms the "simulacrum." The simulacrum is a symbolic order of value. It is our apparent external reality, the "truth" of the order of social existence. However, for Baudrillard, the simulacrum has its roots in the processes of production. In "The Orders of Simulacra," first published in 1976, (Baudrillard 1976, 50-84) Baudrillard outlines the historical development of simulacrum (Baudrillard, 1983). It is in this development of simulacrum that he formalizes the historical development of the object as sign. Social and political status is assigned in relation to the possession of objects. How those objects are produced, therefore, has links to the distribution of status and power within the society. 
In "The Orders of Simulacra," Baudrillard organizes his discussion of the production of the symbolic order into three "orders of appearance:" counterfeit, production and simulation proper. (In his more recent work he discusses a fourth state, the fractal stage.) These stages of historical development are central to his discussion of the object as a commodity and as a representation of social power. According to Baudrillard, the order of the counterfeit arises in the Renaissance as a reaction to the feudal order. He conceptualizes the feudal order as closed system of signs in which all the relations of signs are obligatory: "[a]n interdiction protects the signs and assures them total clarity; each sign then refers unequivocally to a status" (Baudrillard 1983, 84). In the feudal order every sign is inseparably linked to its signifier, and there is no class or sign mobility. However, with the coming of the Renaissance, a new order of signs is born-the counterfeit.

Baudrillard marks the Renaissance as the end of the "obliged sign" (Baudrillard 1983, 85). For Baudrillard, such Enlightenment ideas as human equality, natural law, and transcendental reason force a change in the obligatory feudal order of signs. In the Renaissance, the sign is no longer tied inseparably to its signifier; signs are no longer "obliged," but rather, society has become a "proliferation" of signs "that all classes will partake of equally" (Baudrillard 1983, 85). This lack of obligation is exemplified in the Renaissance concept of "natural law" (Baudrillard 1983, 86). A concept which represents, for Baudrillard, the ambition of bringing all signs under a unitary governing principle.

The Renaissance world was ones in which all signs were governed by the unitary principle of natural law. This project is exemplified in the creation of an order in which 
the substitute takes on the character of the real. In the Baroque period, this substitution was carried out with the use of stucco. Baudrillard sees in the "prowesses of stucco and the baroque art... the new ambition of the Renaissance man," which is "the transubstantiation of all nature into unique substance... [the] ambition to exorcise the natural substance of a thing in order to substitute a synthetic core" (Baudrillard 1983, 87). It is here that Baudrillard first introduces the political and social ramifications of simulacra.

He says, "simulacra are not only a game played with signs; they imply social rapports and social powers" (Baudrillard 1983, 88). The project of creating a world grounded on a unitary principle assumes a certain social and political agenda. For Baudrillard, this agenda is clearly one of "universal hegemony," for "everything testifies already — not in production, but in counterfeit to the same project of control and universal hegemony - to a social scheme where the internal coherence of a system is already at work" (Baudrillard 1983, 89-90). Even at this early stage Baudrillard identifies the logic of simulation as a system of control, a system whose goal is to build the perfect, docile society, in which its hegemony, through the ordering of all signs, is indestructible-a society made out of "plastic" (Baudrillard 1983, 91). However, the Counterfeit order is only the beginning, for the Industrial Revolution augments the production and ordering of signs.

The logic of signs changes in the passing from the Renaissance to the Industrial Revolution.

The first-order simulacrum never abolished difference. It supposes an always-detectable alteration between semblance and reality... The secondorder simulacrum simplifies the problem by the absorption of appearance, or by the liquidation of the real (Baudrillard 1983, 94-95). 
In the Renaissance (the first order) the project was creation, the building of a world based on signs rooted in natural law. In the Industrial period (the second order) the goal is (re)production. With the coming of the Industrial Revolution it is no longer a matter of the singular creation of signs; rather, it is a matter of the equivalent production of signs. Hence, with industry the organizing principle of the sign shifts form "natural law" to "mercantile value."

The intensification of the logic of capitalism and the rises of mercantile value eliminates the need for the sign's relation to its "original (or signified)." Rather in the age of industry, what matters is the total equivalence of signs. Mercantile value, as the industrial base of the sign, is only interested in (re)production. It is only through the ability to mass-produce, through the ability to create a "series," that money, value, and signs come to be distributed (Baudrillard 1983, 97). This leads, according to Baudrillard, to the "obliteration of the original reference," since it is not necessary or valuable to have an "original" in a system whose goal is equivalence. Consequently, with the emergence of the Industrial Revolution, the original is replaced by the logic of the "series." Serial reproduction is, for Baudrillard, "a revolution” (Baudrillard 1983, 99). In reproduction, the techniques of production are the sole determiner of an objects use and exchange value. In this logic there is, according to Baudrillard, no longer a need for the distinction, which Marx makes between use value and exchange value, for both are lost in the equivalence generated by the techniques of reproducibility.

At this stage of capitalism it is the technique of reproduction itself that ascribes all value, meaning, and reality. No longer are products determined by their use value. 
Rather, they are all "conceived from the point-of-view of their reproducibility" (Baudrillard 1983, 100). At this stage, "[o]nly affiliation to the model makes sense, and nothing flows any longer according to its end, but proceeds from the model, the 'signifier of reference"' (Baudrillard 1983, 101). In order to make reproduction possible, there must be a "model" or "code" from which replicas are generated. It is this concept of "code" that, for Baudrillard, proclaims the move into the third order of simulacra, the move from reproducibility to the "code" as the basis of value.

In the third order one enters what Baudrillard calls the "metaphysics of the code" (Baudrillard 1983, 103).

The great simulacra constructed by man pass from a universe of natural laws to a universe of force and tension of force, today to a universe of structure and binary opposition. After the metaphysics of being and appearance, after that of energy of determination, comes that of indeterminacy and the code (Baudrillard, 1983; 103).

For Baudrillard, the single-minded focus of the Industrial Revolution on reproducibility introduces a "new operational configuration... Digitality is its metaphysical principle, and DNA its prophet" (Baudrillard 1983, 103). It is a configuration "whose value is purely tactical... and whose structure is that of a macromolecular code of command and control" (Baudrillard 1983, 104). The productivity of the Industrial Revolution creates a structural configuration in which the process of reproduction has come to constitute the world, in the same way that DNA constitutes the biological world. "The question of signs, of their rational destination, their real or imaginary, their repression, their deviation, the illusion they create or that which they conceal, or their parallel meanings—all of that is erased" (Baudrillard 1983, 104). Just as the basis for all human biology is reducible to the single dimension of the DNA, the 
world (after the success of the Industrial Revolution) is reducible to a form of "binary opposition" and "digitality," in which all reality is reduced to the "the mystic elegance... of the zero and the one" (Baudrillard 1983, 106). In this new order, society has become "an erased record, unchangeable, of which we are no more than cells-for-reading" (Baudrillard 1983, 105).

With the reduction of all value to the single dimension of reproducibility, with the destruction of any value difference between being and appearance, between the real and the represented, reality has, for Baudrillard, imploded into a system of "binary opposition.” In a code-ordered system all questions and answers are always already determined, since, "the code is itself but a genetic cell, a generator where myriads of intersections produce all the questions and possible solutions, so that choices (by whom?) can be made" (Baudrillard 1983, 105). For Baudrillard, the "code" of reproduction emerges as the DNA of social value; it is society's referent, base, and 'teleological principle."

The "code" closes the gap between the real and the illusory by presenting itself as the real; it is that "from which all being proceeds" (Baudrillard 1983, 106). The code is the foundation on which a prescriptive order for social life rests. Once the code is determined, the social and political order are to be shaped in its image. The project of creating a single, unitary conception of reality from which all social and political arrangements follow as a deductive application of "truth" is secured within a new system in which truth and value are determined. It is the exploration of the logic of "the code" which occupies much of Baudrillard's work during the 1980s.

However, in 1987 there is a shift in Baudrillard's thinking concerning the 
logic of the code and the concept of simulation, a shift toward a new concept of the fetish, a shift toward ecstasy rather than desire. Here Baudrillard begins his discussion of the fractal stage.

Everything began with the object, yet there is no longer a system of objects. The critique of the object was based on signs saturated with meaning, along with their phantasies and unconscious logic as well as their prestigious differential logic. Behind this dual logic lies the anthropological dream: the dream of the object as existing beyond and above exchange and use, above and beyond equivalence; the dream of the sacrificial logic of gift, expenditure, potlatch, 'devil's share consumption, symbolic exchange ... All this still exists, and simultaneously it is disappearing (Baudrillard 1987, 11).

Baudrillard contends that the whole system of simulacra, as the analyses of the object as sign, is today disappearing. There are two important distinctions in this shift. The first is the move from the concept of the code, to that of the network. The second is the move from "the system of objects" to "the destiny of the object." In the earlier form of simulation "the code" was the system by which value was assigned and determine. However, in a world of increasing communication the logic of "the code" is replaced by the logic of "the network." With the logic of the network the line between the ordering principle of the code and the object, or signs that it evaluates and organizes, is in a significant sense, completely effaced. In the network objects cease to be signs. Where once there was a relation of objects to the symbolic order in the form of exchange, where once there was the challenge of the code to the object, today there is something beyond objects. This is not to suggest that objects have disappeared; rather it is to suggest that they have become visible only in it relation to the new environment of the network.

The order of symbolic exchange was predicated on a space, a "challenge" between the code and the object. However, in a system ordered by the network there is no 
longer room for the challenge. Baudrillard elaborates his position by saying, "[t]he object itself takes the initiative of reversibility" (Baudrillard 1987, 80). It is in this shift from the code to the network that we enter what Baudrillard calls the "fractal stage of value" (Baudrillard 1993, 5).

Baudrillard describes the fractal stage as what comes "after the orgy." All the substance of the symbolic order, desire, seduction, liberation, all of aspects of symbolic exchange have today returned to haunt the network of social value. At this stage the economy of value becomes pure simulation where "there is no point of reference at all, and value radiates in all directions, occupying all interstices, without reference to anything whatsoever, by virtue of pure contiguity" (Baudrillard 1993, 5). For Baudrillard the system of value has, today, surpassed itself in the complete "contiguity" of the signified and the signifier - the code and the object. However, this raises a question. In a system in which "value radiates in all direction," in a system which has surpassed itself as a system, what can be said about it? What is the logic of a system past logic? The answer is fetishism.

It is in the concept of fetishism that Baudrillard's project takes up a new the question or "destiny" of the object. In his early works, Baudrillard traced the development of the object as sign, which is the logic of simulation. However, with the move from the code to the network, the object and its system are erased. Yet, the object emerges as an object again, but not an object in a real sense. Rather, it is an object as fetish (Baudrillard 2001, 129). The commodity, which once contained elements of use value and exchange value, now has been transformed in to pure symbolic value. This occurs as the commodity now acquires it value only in relation to the network of 
commodities in circulation.

In a system of objects there is a relation and an ordering principle. With the move past the system there is no longer a demarcation between the object and the system, between the symbolic and the sign. Therefore, the object is forced past it own existence, past its ordering principle and into the realm of the fetish.

So initially, the real object becomes sign: this is the stage of simulation. But in a subsequent stage the sign becomes an object again, but not a real object: an object much further removed from the real than the sign itself and object ... outside representation: a fetish (Baudrillard 2001, 129).

At this stage one can no longer talk about either representation or value in a proper sense. Rather one is forced to face the object as beyond representation, beyond good and evil, as pure fetish. Here Baudrillard brings his analyses of the object fullcircle. However, what is it that links his earlier conception of the object to his later conception of the object? What makes Baudrillard's analysis possible and holds his analysis together? The answer is embedded in his relationship to Marx.

\section{Consumption: Both Sign and Fetish}

Baudrillard traces the development of the object from its birth as sign to its quasideath as fetish. Yet a question still remains. What is it that made all of this possible? Out of what process does the hyperreal, the code, the object as sign, the concept of simulation emerge? The answer is "consumerism." In The Consumer Society, Baudrillard asserts that consumption functions as a language. Consumption is a means by which humans 
communicate and interact with one another. Hence, in his analysis of consumption Baudrillard "deploy[s] the whole panoply of tools derived from structuralist linguistics including sign, signifier, signified, and code" (Baudrillard 1970, 6). In this system, "commodities are no longer defined by their use, but rather by what they signify. And what they signify is defined not by what they do, but by their relationship to the entire system of commodities and signs” (Baudrillard 1970, 7). People no longer simply consume objects, but rather they consume objects laden with symbolic meaning, they consume objects, because objects signify more than their use. One's car, one's house, and one's brand of toothpaste are no longer simply objects for consumption, with use and exchange value. Rather they are symbols, signs of one's happiness, success, affluence, or penury.

For Baudrillard, this consumption of objects as signs has thoroughly infiltrated society. "We are at the point where consumption is laying hold of the whole of life" (Baudrillard 1970, 29). All commodities are, according to Baudrillard, laden with symbolic value, which has eclipsed their utility and monetary values. Baudrillard describes the shift to the object as sign as "a revolution which has put an end to [the] 'classical' economics of value” (Baudrillard 1976, 6). In this symbolic system of consumption, the structural value of signs eclipses classical terms such as "use value" and "exchange value." The objects as sign, ordered by the code of simulation, becomes the measure of value: "The system of reference for production, signification, the affect, substance and history, all this equivalence to 'real' content, loading the sign with the burden of 'utility,' with gravity . . . all this is over with” (Baudrillard 1976, 6-7).

Sign value is completely independent of 'real' utility or content. At this level, 
commodities, all of whose values have become symbolically determined, are exchanged and valued only in relation to other signs, only in relation to the system of signs itself. Thus, "[r]eferential value is annihilated, giving the structural play of value the upper hand" (Baudrillard 1976, 6). Real, "referential" value has been replaced by structural play, by the pure, symbolic interplay of signs. It is in the shift from use/exchange value to sign value that the commodity enters simulation proper.

With the shift from use/exchange value to sign value, from referential value to structural value, the commodity loses any necessary cohesion with the "real:" "Now the other [structural] stage of value has the upper hand, a total relativity, general commutation, combination and simulation - simulation, in the sense that, from now on, signs are exchanged against each other rather than against the real"' (Baudrillard 1976, 7). This "emancipation of the sign" from the real is an unavoidable result of the emergence of sign value.

In a symbolic system of value there is absolutely no room for the real as referent. The real is, by definition, non-symbolic and concrete. Therefore, in the system of consumption described by Baudrillard, in which value is purely symbolic, and the object is pure sign, the real has no value as a secure point of meaning. However, rather than being simply an extension of Baudrillard's earlier discussion of the code and simulation, consumerism appears as the process which makes simulation possible. More precisely, it is the shift from the object as use/exchange value to the object as sign value that allows simulation to develop.

In order for reality to implode into simulation, one important shift must occur. The real, the non-symbolic, the concrete commodity must be replaced as the referent of 
value. This is precisely what the shift from use/exchange value to sign value allows. As already discussed, the real cannot anchor a system of value whose point of reference is symbolic, just as the concrete commodity has no place in a system of objects as signs. Therefore, this shift, which makes the referent of value symbolic, rather than concrete, is directly responsible for the elimination of the real in its conventional sense. It is this shift that makes the real obsolete and valueless. In short, the system of objects and simulation, which dominants Baudrillard's early works, is made possible only through his augmentation of the Marxian concept of value and commodity. This unstated logic is implicit in Baudrillard's system. What is important to note is that while it has been argued that Baudrillard's redescription of value represents a complete "break" with Marx, it is possible to assign this analyses another meaning. As Baudrillard himself affirms when he says:

Value thus had a natural aspect, a commodity aspect, and a structural aspect. These distinctions are formal ones ... reminiscent of the distinctions between the particles physicists are always coming up with. A new particle does not replace those discovered earlier: it simply joins their ranks ... So let me introduce a new particle into the microphysics of simulacra ... the fractal stage (Baudrillard 1994, 5).

For Baudrillard, none of the stages of value he illuminates are formal breaks with the Marxian conception of value. Rather they are augmentations which take their place in the "microphysics of simulacra." The concept of simulation and the development of the object as sign are, as shown above, made possible by the augmentation of the Marxian conception of value. Also the later development of the object as fetish, which comes to dominant Baudrillard's later work, is again clearly a development and augmentation of the Marxian concept, for “[i]n Marx's analysis, the formal analysis of the commodity 
grounds a first level fetishism, connected with exchange value. But when the passion for value becomes embodied, beyond value ... this becomes the object of a higher fetishism" (Baudrillard 2001, 129). Thus both Baudrillard's conceptions of the object as sign and as fetish stand in a positive relationship to Marx. This is significant in that it implies an on going relationship between Marx's critical analysis and Baudrillard's project, a relationship most meaningfully expressed as a critique of consumption.

If the rise of simulation and the object as sign are tied to the consumption of signs over commodities (an association that seems reasonable), and if the move to the object as fetish is an augmentation of Marx's concept of fetishism, which itself implies a relation to consumption, then it must be the case that uneven modes of global consumption imply uneven distribution of both simulation as "code" and as "fetish." Further, one can conclude from this association that one would find the highest levels of simulation (in both senses) in societies with the greatest amount of consumerism. This would certainly explain Baudrillard's fascination with the United States.

\section{Simulation, America, and the Production of the Fetish}

America is where the importance of Baudrillard's discussion of symbolic consumption manifests its most acute symptoms. Today, America is the place where simulation and the production of the fetish have reached its zenith. A brief look at statistics shows that America leads the world in consumption. America is five percent of the world's population and consumes forty percent of the world's goods (Chomsky 1994, 
99). What explains the fact that amidst abundance, Americans work the longest hours and have the fewest holidays and vacations? Awash in salad-shooters, microwaves, and handheld computers, what keeps Americans marching ever forward in their consumptive frenzy?

Here the notion of symbolic exchange becomes an important explanatory tool for understanding the conditions of late capitalism. To Baudrillard, America displays the most advanced symptoms of simulation. In his book, America, Baudrillard describes the United States as "astral," appearing to come from the stars, as not from this world. For Baudrillard "there is no truth of America" (Baudrillard 1986, 27). America is, "neither dream nor reality. It is a hyperreality" (Baudrillard 1986, 28). He continues:

The form that dominates the American West, and doubtless all of American culture, is a seismic form: a fractal, interstitial culture, born of a rift with the Old World, a tactile, fragile, mobile, superficial culture - you have to follow its own rules to grasp how it works (Baudrillard 1986, 10).

Baudrillard identifies America as a manifestation of the most advanced stage of simulation, that is, as lacking any grounding in a "real" economy of value. As Baudrillard describes it, "Americans may have no identity, but they have wonderful teeth" (Baudrillard 1986, 34). America has all the signs of culture, history, and identity. Yet if one looks closely, these qualities are nowhere to be found.

But Baudrillard may identify the nation, America, too closely with the process. This can be seen in his contrast between Europe and America. "For the European, even today, America represents something akin to exile, a phantasy of emigration, and, therefore a form of interiorization of his or her own culture" (Baudrillard 1986, 75). America, according to Baudrillard, represents (for Europeans) a kind of exile from one's own sense of culture - an exile from reality. America is a land without its own culture, a 
fascinatingly astral replica of the old world.

America functions, in Baudrillard's system, as the archetype expression of simulation and the fetishism of the object. It is a country without history, culture or identity. America is, for Baudrillard, already lost in the "schizophrenia" of the network and the object as fetish. It is a place where representation and value have become impossible. In Baudrillard's America there is no longer a referent of value; there is only the fetish. Hence Baudrillard concludes, "[America] is without hope" (Baudrillard 1986, 121). Whether or not one agrees with Baudrillard, it is difficult to see America as anything other than a preview of the world's destiny in the age of late capitalism. Clearly, for Baudrillard, the hyperrealization of America is complete.

But is this America or the uneven global process of capitalist development that Baudrillard witnessed in America? If consumerism gives rise to simulation it would simply be logical to assume that uneven production and consumption patterns would lead to uneven development of simulation. If America is more simulated, and, therefore, less real than Europe, then the conclusion can only be that simulation is not evenly distributed across the globe. This means that there are places in the world that are less invested in the real than others. This offers proof that simulation is not globally homogeneous, but does not bring the conclusion that America has a fate that stands outside the process of fetishized production more generally.

Here, Baudrillard may come too close to identifying the fetishized nature of symbolic production with America. America is not the cause of the emerging globalizing network of production. It manifests itself in the West, and those (like Japan) that have moved to the production of symbolic commodities due to the satisfaction of the material 
conditions of reproduction within their domestic economies.

The "American model" of production is determined by its integration into the network of fetishized production. Such a process is not a national phenomenon, as Marx understood, but determined by the conditions of capitalism more generally. It is an example of a society in which production of symbolic value emerges in its fullest manifestation as the satisfaction of material needs (at least for the majority), explored by Marx within the concept of use value, has given way within the economic system. Production, distribution, and consumption are determined by the network of symbolic exchange. This is a necessary development for capitalist production in order to rationalize the expansion of production in the face of increasing productivity of labor.

\section{Baudrillard, Marx, and the Production of Symbolic Value}

In Volume One of Capital, Marx describes what he means by the fetish. "Fetishism" is described as something that "attaches itself to the products of labor, so soon as they are produced as commodities..." (Jordon 1971, 244). Hence, even in Marx there is the idea that products have a value beyond that assigned to them by their use or value in the process of exchange. Fetish value is symbolic, tied to the object as an expression of desire. As Marx says in the Kölnische Zeitung, fetishism is "the religion of the sensuous appetites" (Marx 1967, 115).

However, Marx does not really develop the concept of "symbolic value." In part, this may be explained by his materialism, which ultimately returns to use value to ground 
its discussion of production and social organization. For Marx, sign value may appear to lack true substance, unable to be a sufficient motivator of human activity.

Yet Marx's predictions on social change have not come true. Imperialist policies by the industrial states have kept the domestic conditions of the capitalist economies relatively stable. The working classes in the G-7 countries are not in upheaval, as Marx predicted, despite relatively flat salaries and living standards. However, one can begin to explain this by adding the notion of symbolic value to the Marxian concepts of use value and exchange value, and such an addition puts the present conditions of work, labor, technology and political stagnation in a new light.

The consumption of symbolic value has several features that assist it in maintaining the capitalist order. First, the goods consumed can be inexpensive and made widely available to the public. Second, the commodity need not have a particularly strong use value. This means that the object operates on the level of desire or seduction. One desires or is seduced by the object as possession, not the object as utility. As a result, symbolic commodities do not interfere with the circulation of use value. In fact, they circumvent the utility of use value as a force in maintaining political and economic control over the population (A fact well recognized by both Marx and Baudrillard).

There is another aspect of sign value that distinguishes it from use value. As a fetish is a commodity whose primary value is symbolic, it requires the construction of desire. The fetish must be "sold" to the consumer in a way that bread and clothing need not. It requires a cultural industry that is both linked to the material desires of the working class, and to the capitalist system of production, distribution, and consumption.

Here we return to the Marxian concept of the fetish as a commodity that has use 
value for capital, because it both absorbs the excess capital of the working class, and provides a source of demand for the products of industrial capitalism. The fetish increases the circulation of capital in an economy where use value has largely been satisfied. The Baudrillardian project takes the Marxian concept of fetish to its logical extreme.

As is implicit in Marx's understanding of fetishism, the mass consumption of superfluous symbols keeps the engines of industry humming, long after the needs of those within the industrial state are satisfied. However, according to Baudrillard even this logic of the fetish must at some point give way to a higher order fetishism. Baudrillard suggests that the logic of capitalism will reach a point, as it has in America, in which the very structuring of value itself becomes a barrier to productivity, consumption, and capital. Thus, the capacity of fetishism to sustain the logic of capital increasingly comes to constitute capitalism itself. In the Baudrillardian system, capitalist productivity, consumption, and exchange have been freed from every possible barrier, even that of value. At the leading edge of contemporary capitalism, value increasingly gives way to a new kind of fetishism.

\section{V: Production and Politics in the Symbolic Order}

Today, a political economy based on the production and reproduction of an endless chain of identical products has come to an end. Just as the system of production produced a mass of "signs," it also produced a human mass and the idea of universal humanity composed of identical creatures. Such a notion reinforced the ideas of equality 
and democracy, which were presented as preexisting sub-currents of society. Thus a notion of "human rights" emerges as the Enlightenment mantra, (Baudrillard 2000, 21) as personal liberty emerges as the mirror image of wage-slavery. However, amid the celebration of universal humanity a fatal strategy unfolds.

The rise of the capitalist order brought about a culture in which production for exchange replaced production for self-sufficiency. Mass production was capable of generating abundance far beyond the needs of human beings. Consumer culture arises as the response, a culture in which the symbolic value of good can circulate at a rate that far exceeds the circulation of use value. In that way, capitalism continues to expand.

Here one can see Baudrillard's return to his Marxist roots in altered form. The rise of consumer culture and the simulational order are systems of domination. However, they represent a system in which both the working class and the bourgeoisie are ultimately subject to the dictates of the same economic imperatives. If the system of sign exchange knows no traditional class distinctions this is because, the modes of repression and integration of the simulation order are, in this regard, more comprehensive, more complete, and the prospects for liberation are less optimistic. Consumption integrates rather than alienates and takes on the form of a cultural or national duty that transcends affiliations of class.

The consumption of symbolic goods becomes the means to absorb excess production. It is not enough to have food, clothing, and shelter. One must have the "correct" and trendy commodities in order to be part of the march undertaken by the continual circulation of signs. This addendum to Marx explains how capitalism has continued to survive despite its ability to produce excess. The work force can only remain 
tied to the machinery of production if it believes that it must engage in the circulation of symbolic goods. Here, advertising has a critical role to play in the system of domination that emerges.

Baudrillard is pessimistic about the possibilities of resistance to the simulational order. This is the case because of both its pervasiveness within the advanced states, especially the United States, and because of its transparent nature. The self-referencing "truths" of a consumptive order obsessed with signs does not allow the dissemination of alternatives, which escape its symbolic "code." Further, such an order is very seductive. It is not clear that people would really want more time with their families and a less repressive political climate if it meant they had to abandon their cell phones and saladshooters.

These developments have transformed the activities of politics. Today there is barely even lip service to the idea of the social contract. With a sign economy, there is no longer the need to strike a bargain with the masses. State power now devourers the state's own people and cities, just as it once sought to destroy its enemies (Baudrillard 1993, 79). For Baudrillard, the contest today is between an infantile mass and a totalitarian system maintained by self-reference to the code (Baudrillard 1993, 78). The state uses new powers of simulation (the fusion of the military industrial complex and info-tainment elites) to further its power (Baudrillard 1993, 79). Even when it engages in the use of brutality, the state feels justified in criticizing those who react to its repression with violence (Baudrillard 1993, 78).

Resistance to institutional power in the age of control by the code, and a mass logic that hypnotically draws one toward fetishism takes various forms. The illicit use of 
narcotics is one reaction to the process of rationalization and forced submission to the dictates of a state power by the economy of the sign (Baudrillard 1993, 67). Terrorism is a reaction against the attempt at universalization, whether through political acquiescence, universal commodification, or genetic blueprinting. And neurosis (or what Baudrillard calls "isophrenis") becomes another form of resistance to the madness presented by the current situation (Baudrillard 1993, 67).

Such resistance is personal, local, and immediate. It does not take the form of a new metanarrative, universal ethic, or construction of human identity. It is raw, unrefined, reactive energy. Thus, "singularity" emerges as the form resistance takes within an increasingly predetermined, preordered, and preselected social order. Resistance is, for Baudrillard, neurosis struggling against madness (Baudrillard 1993, 67). To paraphrase Nietzsche in this context, when the world is so ordered, when the code is so strongly engaged in a simulation of the real, all those who see the world for what it is will go voluntarily to the madhouse.

\section{Conclusion}

The significance of Baudrillard for the traditions of Marxism and critical theory cannot be denied. By developing the Marxian concept of the fetish, in his system of sign value, Baudrillard extends the explanatory power of the Marxian paradigm. The commodity possesses three values: use value, exchange value, and symbolic value. Symbolic value is what emerges with simulation. It is a product of the social 
transformation and change that has occurred with the rise of the new historical conditions of production and technology. However, Baudrillard does not simply stop with a structural analysis; rather he follows the logic of symbolic exchange and fetishism further, suggesting that there will soon be a time when the phenomenon of capitalism will be past the point of analysis, past the very possibility of being critically examined. In fact, he argues that this time has already come for America.

In a significant sense, Baudrillard represents a continuation of the Marxian project in a world that is losing the ability to critically examine its direction. Baudrillard continues the maxim represented in Marx, that the economic order is going to be a major, if not "the" major influence in determining the direction of social institutions and activities. Thus, whether one agrees with the extremism of Baudrillard's argument or not, it is difficult to deny the existence of a kind of symbolic economy and its power to affect the social order.

However, when it comes to a strategy for resistance, Baudrillard is not Marx or Foucault. It is hard to see a positive program of political opposition emerging out of Baudrillard. His pessimism about the future is not matched with a plan for action. Resistance is personal and private. It does not take the form of a coherent political movement.

Baudrillard is more the messenger. However, from Baudrillard's analysis it is clear that any collective political response would have to include a serious examination and rejection of consumer culture. This would mean a confrontation with the ethos of the tendencies of late industrial capitalism. It is hard to imagine the triumph of such action under the current conditions, even if it is possible see what form such action should take. 
However, until such a strategy is formulated, we are likely to continue on until the last computer is unplugged and the last commercial has played.

\section{References}

Baudrillard, Jean. 1986. America, Trans. Chris Turner. Verso: New York.

Baudrillard, Jean. 1970. The Consumer Society, Trans. J.P. Mayer. Sage Publication: London.

Baudrillard, Jean.1983. Simulations, Trans. Paul Foss, Paul Patton and Philip Beitchman. Semiotext[e]: New York.

Baudrillard, Jean. 1976. Symbolic Exchange and Death, Trans. Hamilton Grant. Sage Publication: London.

Baudrillard, Jean. 1988. Jean Baudrillard: Selected Writings, Edited by Mark Poster. Stanford University Press: Stanford

Baudrillard, Jean. 1993. The Transparency Of Evil, Trans. James Benedict. Verso: New York.

Baudrillard, Jean. 2000. Vital Illusion, Ed. Julia Witwer. Columbia University Press: New York.

Baudrillard, Jean. 2001. Impossible Exchange, Trans. Chris Turner. Verso: New York.

Chomsky, Noam. 1994. Secrets, Lies, and Democracy, Odonian Press: Chicago.

Hagerty, Paul. 2004. Jean Baudrillard: Live Theory, Continuum: New York.

Gane, Mike. 2000. Jean Baudrillard: In Radical Uncertainty, Pluto Press: New York.

Genosko, Gary. 2006. "The Spirit of Symbolic Exchange: Jean Baudrillard 's 9/11."

International Journal of Baudrillard Studies, Vol 3, Num 1. Accessed on March 1, 2006

Online at: www.ubishops.ca/baudrillardstudies/vol3_1/genosko.htm, pp.1-11.

Jordon, Z.A. Ed. 1971. Karl Marx: Economy, Class, and Social Revolution, Scribner: New York. 
Kellner, Douglas. 1989. Jean Baudrillard: From Marxism to Postmodernism and Beyond, Stanford University Press: California.

Kellner, Douglas. 2006. "Jean Baudrillard After Modernity: Provocations on a Provocateur and Challenger." International Journal of Baudrillard Studies, Vol. 3, Num 1. Accessed on March 1, 2006. Online at: www.ubishops.ca/baudrillardstudies/vol3_1/kellner.htm, pp.1-32.

Marx, Karl. The Economic and Philosophical Manuscripts of 1844, New York: International Publishers, 1964.

Marx, Karl. 1967. Writings of the Young Marx on Philosophy and Society, Doubleday: New York.

Poster, Mark. Ed. 1988. Selected Writings of Jean Baudrillard, Stanford University Press: California 